\title{
TOURISM AND LOCAL DEVELOPMENT IN THE CRIȘUL REPEDE VALLEY, BIHOR COUNTY, ROMANIA
}

\author{
Varodi Mihaela OLĂU * \\ Ph.D. candidate, University of Oradea, Faculty of Geography, Tourism and Sport, 1 University Street, Oradea, \\ Romania, e-mail: oradeanu_miha@yahoo.com
}

\section{Dana Carmen MIHINCĂU (MIHELE)}

Ph.D. candidate, University of Oradea, Faculty of Geography, Tourism and Sport, 1 University Street, Oradea, Romania, e-mail: danamihincau@gmail.com

\section{Laura Mariana HERMAN (LACATOȘ)}

The Basin Water Administration Crişuri Oradea, 35, Ioan Bogdan Street, 410 125, Oradea, Romania, e-mail: lauralacatos@yahoo.com

\section{Sorin FURDUI}

Ph.D. candidate, University of Oradea, Faculty of Geography, Tourism and Sport, 1 University Street, Oradea, Romania, e-mail: sorin1182@yahoo.com, sorinfurdui1182@gmail.com

\section{Maria GOZNER}

University of Oradea, Faculty of Geography, Tourism and Sport, 1 University Street, Oradea, 410 087, Romania, e-mail: mgozner@uoradea.ro

Citation: Olău, V. M., Mihincău (Mihele), D. C., Herman (Lacatoş), L. M., Furdui, S., \& Gozner, M. (2019). Tourism and Local Development in the Crișul Repede Valley, Bihor County, Romania. Analele Universităţii din Oradea, Seria Geografie, 29(2), 124-132. https://doi.org/10.30892/auog.292113-830

\begin{abstract}
The present study aims to analyze the influence of tourism activity on the environment in the protected area Defileul Crișului Repede, Bihor County, Romania. In this sense, using a series of specific methods, methods and analysis techniques (field observation, analysis and synthesis), the role of tourism in the local economy, its impact on the environment and the socio-economic component were analyzed. The conclusions of this scientific endeavor highlighted some positive aspects regarding the development of tourism in this protected area. As a result of this, after consulting the population and the local authorities, there was an attempt at identifying some recommendations and measures to implement a sustainable tourism, in accordance with the needs of the local population, which will contribute to the diversification and development of the local economy.
\end{abstract}

Key words: Crişul Repede Nature Reserve, Sustainable Development, Sustainable Tourism 


\section{INTRODUCTION}

The Defileul Crisului Repede reservation with an area of 219.70 ha is located in the central part of Bihor county, in the Pădurea Craiului Mountains, between the towns of Suncuiuş and Vadu Crişului, on both sides of the Criş Repede, along the county road. DJ108I and the Cluj-Oradea railway bus (Herman et al., 2019b; Olău, 2019). Considering the floristic, faunistic and geological importance of this area, through Law no. 5 of March 6, 2000 regarding the approval of the Plan for the development of the national territory - Section III - protected areas an area of 219.40 hectares was declared a protected area, it overlapping over the area of Natura 2000 Site Defileul Crişului Repede Pădurea Craiului. Natura 2000 site The Crişului Repede - Pădurea Craiului defile, ROSCI 0062, is part of the Natura 2000 Ecological Network, having functions in the conservation, protection and capitalization of the natural heritage in order to promote and impose a sustainable social-economic development of the territory (Tatar et al., 2018; Ianoș et al., 2009; Ilieș et al., 2018). The Natura 2000 Romania Ecological Network with an area of 5555854.13 ha, respectively 23\% of the surface of Romania (Ilieș et al., 2017) consists of 383 Special Areas of Conservation (SAC) and 148 Special Protection Areas (SPA) with a major role in conservation the species and habitats provided in the annexes of the two directives: "Habitats" 92/43 / CEE and "Birds" 79/409 / CEE.

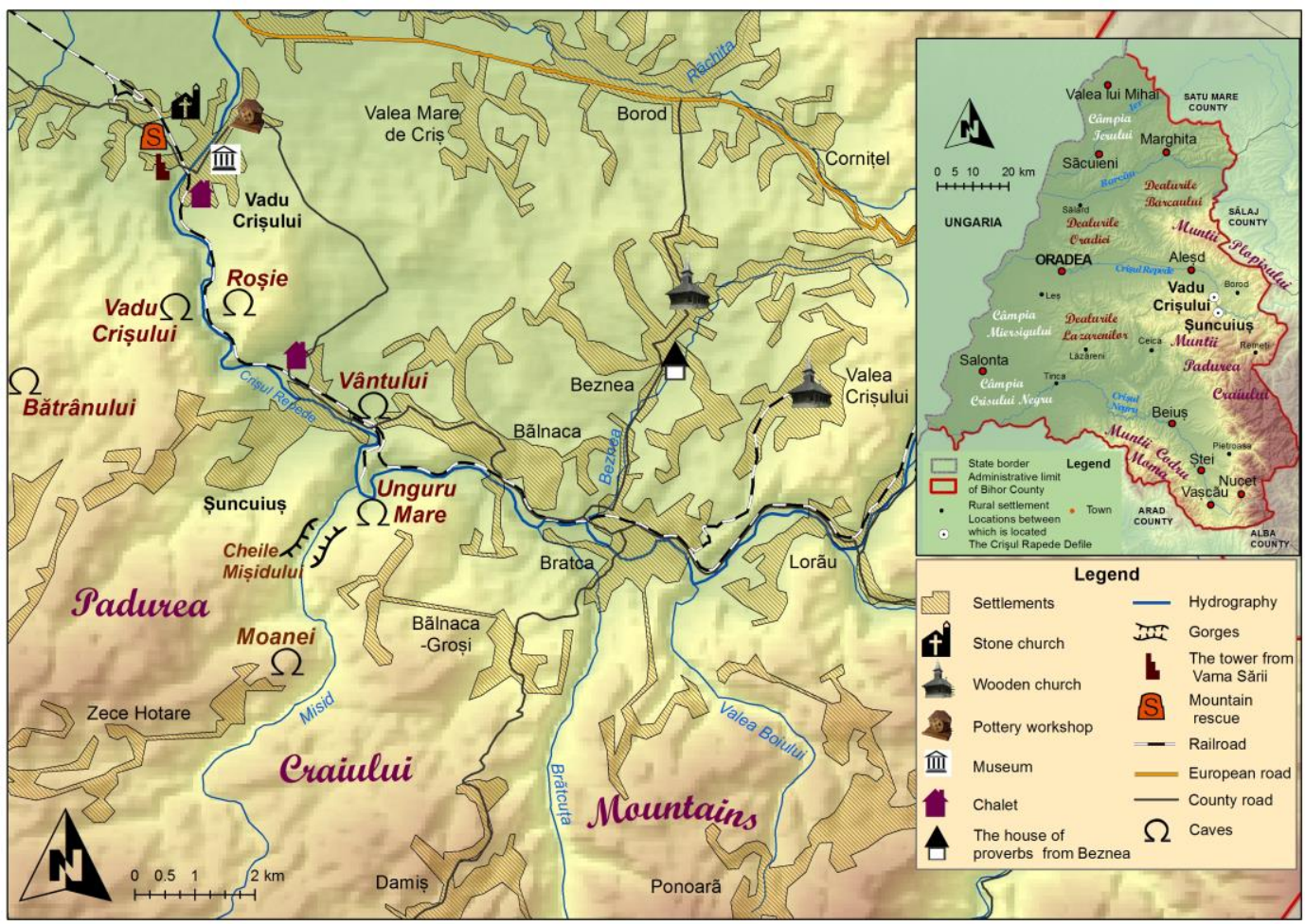

Figure 1. Physical geographical location

The physical-geographical characteristics and spatial location favored the existence of 16 types of habitats, as well as numerous species of community interest, provided in Annex II of Council Directive 92/43 / EEC (16 species of mammals, 3 species of amphibians and reptiles; 5 species of fish; 2 species of invertebrates; 3 species of plants. In addition, other important species of flora and fauna coexist. The natural habitats representative for the area of Natura 2000 site. deciduous, coniferous and mixed forests (Standard sheet Nature, 2000 - Defileul Crișului Repede Pădurea Craiului, ROSCI0062). 
In this context, it is necessary to analyze the way in which tourism could be a factor generating local development, by creating new jobs and sustainable exploitation of the existing tourism potential (Rojanschi et al, 2004; Herman et al., 2017; Ilie et al., 2017). The implementation and development of sustainable tourism can contribute to a better capitalization of the protected area analyzed, with direct social and environmental benefits (raising the awareness among the population regarding the ecological importance of the fauna and flora, as well as the need for their conservation, strengthening cohesion at community level), economic (new jobs, technical and urban infrastructure development, improving living conditions) and identity (increasing interest in one's own culture). Tourism has "a considerable impact on the economies, societies and cultures of the different countries of reference" (Pierre, 1986). It can help maintain local cultural identity (Caciora et al., 2019; Herman, 2012; Herman and Gherman, 2016; Herman and Benchiș, 2017; Herman et al., 2018b), which might otherwise be lost in the dominant trend of globalization (Clark, 1997; Held et al., 1999; Kacowicz, 1999; Herman et al., 2016; Herman and Grama, 2018). The involvement of local communities in the development and functioning of tourism is an important condition for the conservation and sustainable use of local heritage.

\section{RESEARCH METHODOLOGY}

In order to carry out the present study I have resorted to the study of the specialized literature and to the field research. The methods used were field observation, analysis and synthesis of the results thus obtained. During the field activity were held discussions with 25 people from the locality from various fields of activity, among which were the tour guide Ungur Carmen (from Bălnaca village, owner of the land around the Ungurul Mare cave, passionate about speleology and site history archaeological of the cave), a local shepherd, originating from the village of Şuncuiuş, owner of a sheep herd, a local from the area of Vadu Crişului who was in charge of gathering medicinal plants and berries, the owners of the Perla Albastra Hostel in Şuncuiuș, a family of local entrepreneurs who deal with raising cattle for milk and have opened milk distribution points throughout the commune Șuncuiuş, by placing milk dispensers.

\section{CONSERVATION AND PROMOTION OF NATURAL AND CULTURAL- HISTORICAL HERITAGE}

Although the area studied has many caves, enhanced by tourist arrangement are only Vadu Crişului Cave and Unguru Mare Cave. Vadu Crişului Cave is located in the center of the gorge sector between the towns of Şuncuiuş and Vadu Crişului, on the left bank of Crişul Repede, near the stop. The cave that serves it on the railway. Undergoing a rehabilitation project in 2004, the cave impresses with the richness of the speleothems, the cave fauna but also through the underground stream that is thrown into the waters of Criș through an impressive waterfall, itself a tourist objective. The Unguru Mare cave is located in the first sector of the gorge, developed between the localities of Bălnaca-Șuncuius, which impresses through the great meander created by the Crișul Repede river, in the form of a horseshoe at the base of Simion's Hill, thus completing the tourist offer of the area. It is worth noting the importance of tourism for the conservation of the archaeological site of the Unguru Mare Cave. The tourist visits and the creation of an interior museum led to the introduction of the cave in the tourist circuit.

Immediately downstream are located the Mișidului Gorges and two other cavities, the Cave of the Wind (Peștera Vântului) with a length of $47 \mathrm{~km}$ and the Cave of Moana (Peștera Moanei), known for its prehistoric remains. Both, along with eight other caves in the Pădurea Craiului Mountains, were included in the network of specialized speleological tourism (starting with 2016 the first network of species-based caves in Romania was made sustainable development of the karst heritage), through a European financing project regarding the arrangement of the main caves in the karst ensemble existing in the Pădurea Craiului Mountains, under the coordination of the CAPDD. The common element in the arrangement of the entire cave system is the preservation of the natural geological and biological elements as real as possible. By the impressive number, as 
well as by the spectacular and monumental nature of the underground landscapes (palentological vestiges, erosion terraces, meanders, horns, waterfalls, large variety of speleotherms), the caves represent important tourist resources.

The richness and beauty of the natural heritage of the Defileul Crișului area is complemented by the diversity, beauty and uniqueness of the cultural-historical heritage elements represented by architectural monuments such as the Vadu Crișului Wall Church (BH-II-mB01224) or the Tower of Salt Customs "Portus Criș" or Casa Zmăului (BH-II-mB-01023). ${ }^{1}$ Built in the $13^{\text {th }}$ century on a rock near a cave at the exit of the Defileul Crișului Repede on the right, it had the role of overseeing and clearing the floats carrying salt on Criș. The barren spine-type fortification on Simionului Hill - Șuncuiuş dating from the Iron Age is in the attention of the authorities for a future valorization, by revealing the traces of the fortification and its inclusion in the tourist circuit. The wooden churches that have been preserved in Beznea and Valea Crișului, the ethnographic and religious museum in Vadu Crișului, the House of Proverbs in Beznea, the potter's workshop Petru Hașas in Vadu Crișului are other examples of heritage identity with the possibility of valorisation through tourism (Herman and Wendt, 2011; Ilieș et al., 2016). The pottery workshop Petru Hasas can be constituted as a model of economic valorization of an ancient craft, the white ceramics decorated with dark brown specific to the town of Vadu Crișului is unique in the country. The originality, the extraordinary elegance characterized by simplicity creates a note of timelessness that allow it to be present in the contemporary as decorative pieces.

One of the most recent projects (September 2018) under the Interreg Va Romania Hungary 2014 - 2020 Program, which has as an investment priority the conservation and protection of nature on both sides of the Romanian-Hungarian border (Pronature), aims at the rehabilitation and transformation of the Cabin Vad (Zichy) in a visiting center with thematic exhibition spaces but also the creation of a Center for the Promotion of the traditional culture - the Olar House in order to protect and conserve the community resources through events. ${ }^{2}$

Another positive effect on the preservation of the cultural heritage of the region is the inclusion of historic wooden churches in the tourist circuit. For this purpose, the wooden church of St. Archangel Michael and Gavriil-from Valea Crișului was included in the route organized on the occasion of the rediscover the Bihor Bicycle-Road of the Wood Churches. This type of tourist activity, has the role of promoting the wooden churches historical monuments from Bihor county and implicitly from the Crișul Repede Gorge, to be taken into account as cultural tourist objectives, with the purpose of preserving, monitoring and restoring them, for a sustainable tourism. in the region.

Thus the anthropic objectives, in addition to the natural ones, come to complete the tourist complexity of the parade and to contribute to attracting as many tourists as possible. When visiting these wooden churches historical monuments, activities of cyclotourism, tasting of traditional products and hiking are combined (Dincă et al., 2012; Ilieș et al., 2013).

The immaterial heritage that is also valuable is promoted and exploited by the folkloric ensembles in the area or in some festivals, the best known, with a long tradition being the Fair of the Salt Hall. It promotes traditional culture through the parade of folk ensembles in Bihor. Although it takes us more to a peasant celebration than to an ethno-folklore festival, it reminds us of the salt clearance on Crișul Repede at the entrance to the town and through longevity, this year the edition with number 51 took place, benefiting from a wide recognition.

Among the most representative forms of tourism are the tourism, in Vadu Crișului and Unguru Mare Cave arranged for mass tourism, specialized tourism in the Wind and Moana Cave, mountaineering / climbing and mountain hiking, with old tradition, or more recent forms very well received in tourists like rafting, via ferrata and cycling. Crișului Repede Gorge is a nationally known climbing area with 20 sectors, totaling 281 routes. Via ferrata is practiced on four routes,

\footnotetext{
${ }^{1}$ www.cimec. ro

${ }^{2}$ https://oradeaindirect.ro/cabana-vadu-crisului-va-fi-transformata-intr-un-centru-multifunctional/
} 
the Fairy Wall and the Casa de la Zmeului, the route within the Montana Land adventure park and the Hodoaba Valley trail located on the wall of the Unguru Mare Cave next to the Tyrolean which leads to the transformation of the area. ${ }^{3}$ Great Unguru Caves in a real adventure area. Rafting is practiced on a distance of about $3 \mathrm{~km}$ between Șuncuiuș, next to the Unguru Mare cave towards Vadu Crișului, the area with the most attraction which has three more difficult areas.

Starting with the year 2017, in Şuncuiuş, there is an important mountain running competition Primavera Trail Race which was the basis for the subsequent marking of the running routes. Most of the hiking trails in the Pădurea Craiului Mountains are marked in, or starting from, the Crișului Repede Gorge, 7 of 13, and in the gorge to the Vadu Crișului Cave, the thematic route "Without a trace!" Was created, an informal education tool. for the environment and for the appreciation of the values of the protected area. Since 2013, a mountain guard has been operating in Şuncuiuș, which, besides the protection and rescue services in the mountain area, promotes mountain tourism.

\section{LOCAL ECONOMY}

Tourism has proven to be one of the most dynamic economic sectors both globally and locally, with remarkable effects in terms of sustainable development of local economies (Bercu, 2015; Boccella et al., 2016; Drăghici et al., 2015; Dumitru, 2007; Herman et al., 2017; Herman et al., 2018a; Ilie et al., 2017; Rogerson, 2015; Rojanschi et al., 2004; Pires et al., 2015). The idea of adopting the concept of sustainable development in tourism emerged in the last period, thus creating sustainable tourism (Butler, 1999; Carlo, 2014; Xin et al., 2013). Thus, the sustainable development of tourism starts from the idea that the economy and the environment are two facets of the same currency, so, like them, they are inseparable (Sharpley et al., 2015).

The Crisul Repede Gorge is represented in terms of population by 7199 inhabitants, 3543 women, 3596 men, belonging to two territorial administrative units, namely Suncuius (3147 inhabitants) and Vadu Crisului (3992 inhabitants) (INS, 2019).

For most of these inhabitants the work of the land is the only source of income, despite the fact that the share of arable land in the total land is low (16\%, 2283 ha, of which 1016 in Suncuius: 1267 in Vadu Crisului), and, from a pedological perspective, these they do not constitute valuable agricultural land. On the other hand, the high share of pastures and meadows $(43 \%, 6262$ ha, of which 3526 in Suncuius: 2736 in Vadu Crisului), which could be a very valuable base for launching animal breeding and capitalizing on animal products (INS, 2014).

The local economy is marked by the loss of the most important activity generating income and creating jobs, the mining company in Suncuius. Currently, Former Mining Exploitation Şuncuiuş is part of the group of companies Bega Minerale S.A. from Timisoara, which is currently exploiting clay. In the locality there are 26 other economic agents, all with wholly private capital, carrying out their activity in various fields, such as: trade, production (bakeries, detergents and cleaning products, food) or services.

Tourism in the Crisului Repede area is represented by the existence of 5 accommodation structures, respectively 184 accommodation places.

The analysis of arrivals at the level of 2018 highlights 3591 arrivals (3091 in Suncuius: 500 in Vadu Crisului), divided into typological categories as follows: in hostels (1200 arrivals in Suncuius), in student camps and preschools (1090 arrivals, in Suncuius) and in Agrotourism pensions (1301 arrivals, of which 801 in Suncuius: 500 in Vadu Crisului) (INS, 2018).

The analysis of overnight stays at the level of 2018 highlights 9564 overnight stays (7331 in Suncuius: 2233 in Vadu Crisului), divided into typological categories as follows: in hostels (2945 overnight stays, in Suncuius), in student camps and preschools (3257 overnight stays, in Suncuius) and in Agrotourism pensions (3362 overnight stays, of which 1129 in Suncuius: 2233 in Vadu Crisului) (INS, 2018).

\footnotetext{
${ }^{3}$ http://alpinismbihor.ro
} 
The analysis of the tourism situation in the area related to the Crisului Repede Defileu shows us that, at present, although there are numerous tourist activities, in the economy of the area, tourism does not play a very important role, despite the numerous natural and anthropic resources with a high tourism potential. The tourist activities that take place in the area, although in full development, do not yet capitalize on the true capacity and value the natural and culturalhistorical heritage of the Crişului Repede Gorge. Abandoned tourist infrastructure such as the Vadu Crişului stop, the Vadu Crişului cabin, the restaurant in Şuncuiuş in the Unguru Mic cave area are testimonies of a difficult period characteristic of the two decades that followed the events of 1989, when the economic problems of the area faced with the cessation of industrial activities marked tourism in the area of the gorge. Thus it is imperative to develop a development strategy in which tourism is given due importance.

\section{ENVIRONMENTAL ACTIONS}

Tourism, viewed as an economic activity, has both positive and negative influences on the environment. However, we believe that, given the existence of a concrete strategy to capitalize on the strengths of an area in accordance with the principles of sustainable development, the impact on the environment will be positive. This implies ensuring the balance between the economy, society and the environment, thus "tourism, under the conditions of an organized, rational exploitation, does not destroy its own resource" (Cocean 1995, p. 10). Tourism can provide the motivation for a clean environment. This is possible by managing the pollution of water, air, soil, as well as by increasing the aesthetics of the environment through landscaping programs (Herman, 2009; Herman et al., 2019a).

The protection of natural areas can also be a positive impact of tourism, by establishing the protected area regime, being a recognition of the invaluable value that nature concentrates in certain areas. Crișul Repede Gorge is a protected area of national interest included in the 4th IUCN, being a mixed nature reserve. The surface of the reserve is 219.70 ha representing floristic importance due to the presence of vascular plants: species of cormophytes, fern, equisetatae species (horse tail), faunal importance by the presence of species of mammals wolf, deer, wild boar, foxes, rabbits, birds and fish, geological importance due to the limestone in the gorge and the caves included in the reserve over which the site of community importance ROSCI0062 Defile Crisului Repede - Pădurea Craiului, with an area of 40,270 ha. Natura 2000 sites aim not only to protect nature, but also to maintain long-term natural wealth, to ensure the resources needed for socio-economic development (Herman et al., 2016a, b; Ilieș et al., 2015; 2017; Tătar et al., 2017; Wendt et al., 2019). "When defining these sites did not start from the idea of strict protection, which would prohibit human activity. On the contrary, it is considered that in many situations human activities of natural resource management can continue. In many cases the presence of habitats and species in Natura 2000 sites is due in particular to the way in which forests, pastures or grasslands have been managed for hundreds of years". 4 Activities such as traditional agricultural ones, such as growing and obtaining organic products - vegetables, fruits, dairy products, meat, fruit juices, hunting and fishing activities, can and should continue due to their contribution to the diversification and completion of the tourism offer.

The protection actions include specific projects such as the Conservation of bat species in the Pădurea Craiului, Bihor and Trascău Mountains, LIFE08 NAT / RO / 000504, co-financed by the European Union through the financial instrument LIFE + Nature and Biodiversity, carried out between 2010-1013. Following its implementation, the visit routes were changed to bypass the sensitive areas in the Vadu Crişului Cave with important bat colonies, but with high tourist flow the conditions of artificial lighting were changed, the wastes were eliminated, the panels were placed warning in frequented areas or at the entrance. ${ }^{5}$

\footnotetext{
${ }^{4}$ www.emenatura2000.ro

${ }^{5}$ http://apmbh-old.anpm.ro/Mediu/Programe,\%20Proiecte,\%20Relatii\%20internationale-134
} 
The Center for Protected Areas and Sustainable Development Bihor (CAPDD Bihor) has proposed to maintain or improve the conservation degree of the bird species of conservative interest and their habitats, in the area between the Defile Crisul Repede and Valea Iadului, the area designated as Site of Avifaunistic Protection (ROSPA 0115 Crişul Repede - Valea Iadului Defileu) within the project Improving the state of biodiversity conservation in ROSPA0115 (2017-2020). Within the project, biodiversity assessment studies will be prepared, mapping of the distribution areas for the species of birds of community interest and their habitats will be carried out and measures will be established to maintain or increase the conservation degree. The proposed activities also aim to diversify tourist activities, as a viable alternative to the sustainable development of the area. This will be done under the conditions of applying an adequate visitor management, able to ensure the preservation of the environmental characteristics that determine the tourist value of the area itself. ${ }^{6}$

One of the most important projects for the supervision and management of waste was initiated and approved by the Bihor County Council through the Bihor Destination Management Agency. The project Implementation and installation of a surveillance system to monitor the areas where waste is dumped illegally during Crișul Repede is an important step towards supporting the tourist activities from the visible gorge marked by the accumulated waste in the waters of Criș Repede due to waste management problems in the localities. ${ }^{7}$ It is obvious here the positive role of tourism and the repeated warnings of tourists in the area of Crișul Repede Defile. This surveillance measure should be duplicated by measures aimed at educating, empowering and managing waste at the level of local communities in the defile area.

\section{CONCLUSIONS}

Tourism in the area of Crişul Defede Defile is defined by: the level of development of the tourist infrastructure although in development in the last years it offers still reduced possibilities of exploiting the tourist potential of the gorge where the seasonal character of the tourist activities which makes it not an activity basic to ensure permanent character gains, the flow of uncontrolled tourists, the existence of unmanaged caves, thus open to tourism with the risk of their destruction, the existence of the risk of alteration or degradation of habitats.

Currently, the region is carrying out projects aimed at preserving and promoting heritage, protecting and conserving biodiversity, and supporting sustainable tourism development, some funded by the County Council, others funded by European programs. It should also be mentioned the partnerships of local NGOs with results of successful examples.

In support of the sustainable development of tourism in the Crişul Repede Gorge, local authorities should consider a strategy that aims to extend the tourist season, to conserve the natural environment and to promote the objectives with tourism potential. Also for effective management of the area, information and awareness-raising actions are needed among the local communities, in conjunction with the mapping of the protected area, so that there is a database on the plots and the modalities of their use. Information and awareness of the owners regarding the use of the land, the allowed economic activities, as well as the idea of generating sustainable activities, will have a positive impact on the environment in general and biodiversity in particular.

\section{REFERENCES}

Bercu, A. M. (2015). The Sustainable Local Development in Romania-Key Issues for Heritage Sector. Procedia-Social and Behavioral Sciences, 188, 144-150.

Boccella, N., \& Salerno, I. (2016). Creative economy, cultural industries and local development. Procedia-Social and Behavioral Sciences, 223, 291-296.

\footnotetext{
${ }^{6}$ http://www.capdd-bihor.org/2018/03/28/lansarea-proiectului-imbunatatirea-starii-de-conservare-a-biodiversitatii-inrospa-0115-defileul-crisului-repede-valea-iadului/

${ }^{7}$ https://www.transilvaniabusiness.ro/2019/11/13/defileul-crisului-repede-supravegheat-si-monitorizat-cu-22-de-camere-video/
} 
Butler, R. W. (1999). Sustainable tourism: A state-of-the-art review. Tourism geographies, 1(1), 7-25.

Caciora, T., Herman, G. V., \& Kéri, G. (2019). Prospect Study of the Cellars in Sălacea, Bihor County, Romania. Analele Universităţii din Oradea, Seria Geografie, 29(2), 40-45.

Carlo, A. (2014). Sustainable Tourism in Practice: Promoting or Perverting the Quest for a Sustainable Development? Sustainability, 6 (5), 2562-2583.

Clark, I. (1997). Globalization and Fragmentation: International Relations in the Twentieth Century, Oxford University Press, Oxford, USA.

Cocean, P. (1995). Peşterile României-potențial turistic, Editura Dacia, Cluj-Napoca.

Council Directive 79/409/EEC of 30 November 2009 on the conservation of wild birds

Council Directive 92/43/EEC of 21 May 1992 on the conservation of natural habitats and of wild fauna and flora.

Dincă I., Herman G.V., Sztankovics G. (2012). Descoperire prin ecoturism si prin turism rural în Comuna Cetariu [Discovery through ecotourism and rural tourism in Cetariu], Editura Universităţii din Oradea, ISBN 978-606-10- 0724-0, Oradea.

Draghici, C. C., Pintilii, R. D., Peptenatu, D., Comanescu, L. G., \& Sirodoev I. (2015). The Role of SPA Tourism in the Development of Local Economies from Romania. In: Iacob Al. 2nd Global Conference on Business, Economics and Management and Tourism (BEMTUR), October 29-31, 2014 - Prague (Czech Republic), Elsevier Science Bv, Amsterdam, Netherlands, pp. 1573-1577.

Dumitru, N. (2007). Contribuţia turismului în procesul creşterii economice, Jurnal of tourism [No.3]: http://www.revistadeturism.ro/rdt/article/view/233/141. vizitat: 18.04.2017

Formularul Standard Nature 2000 pentru ariile de protecție (SCI), - Defileul Crișului Repede - Pădurea Craiului, ROSCI0062 [Standard sheet Nature, 2000 (SCI) - Defileul Crișului Repede - Pădurea Craiului, ROSCI0062].

Held, D., McGrew, A., Goldblatt, D., ... \& Perraton, J. (1999). Global Transformations: Politics, Economics, Culture, Policy Press, London, United Kingdom.

Herman G. V. (2009). Omul şi modificările antropice din Câmpia Someşului [The man and anthropogenic changes in Somes Plain], Editura Universităţii din Oradea, 227 pag., ISBN 978-973-759-981-0, Oradea.

Herman G. V. (2012). The Role and the Importance of Historical Monuments in the Diversification of Touristic Services in Oaș Land. Forum Geografic, Studii și cercetări de geografie și protecția mediului, 11(2), 229-234.

Herman G. V., \& Gherman V. (2016). Identification, quantification and analysis of the ethnographic potential of folk songs specific to Bihor, Romania. Analele Universităţii din Oradea, Seria Geografie, 26(2), 261-267.

Herman, G. V., \& Benchiș, L. B. (2017). Fairs, forms of expression of the local identity. Case study: Beiuș fair, Bihor County, Prospect Study of the Cellars in Sălacea, Bihor County, Romania 45 Romania. Analele Universităţii din Oradea, Seria Geografie, 27(1), 108-113.

Herman, G. V., \& Grama, V. (2018). Geographical Aspects of Space-Time Evolution of Independent States. Revista Română de Geografie Politică, 20(2), 49-56.

Herman, G. V., \& Wendt, J. (2011). Development and Promotion of Tourism, an Extra Chance in Maintaining and Asserting the Identity and Specificity of Oaş Land. GeoJournal of Tourism and Geosites, 1(7), 87-95.

Herman, G. V., Deac, A. L., Ciobotaru, A. M., Andronache, I. C., Loghin, V., \& Ilie, A. M. (2017). The role of tourism in local economy development. Bihor County case study. Urbanism. Architecture. Constructions/Urbanism. Arhitectura. Constructii, 8(3), 265-274.

Herman, G. V., Grama, V., \& Stupariu, I. (2016). The international organisations between globalization and regionalization. Case study: world tourism organization. Revista Română de Geografie Politică, 28(2): 49-59.

Herman, G. V., Ilieș, D. C., Baias, Ș., Măduța, M. F., Ilieș, A., Wendt, J., \& Josan, I. (2016a). The tourist map, scientific tool that supports the exploration of protected areas, Bihor County, Romania. GeoSport for Society, 4(1), 24-32.

Herman, G. V., Ilieș, D. C., Măduța, M. F., Ilieș, A., Gozner, M., Buhaș, R., \& Mihók-Géczi, I-M-T. (2016b). Approaches regarding the importance of Natura 2000 sites' settings pupil's education through geography. Case study: Valea Rose (Red Valley) Natura 2000, Bihor country, Romania. Journal of Geography, Politics and Society, 6(4), 57-62.

Herman, G. V., Peptenatu, D., Grama, V., \& Pintilii, R. D. (2018a). Tourism and Local Development. Study Case: Băile Felix-Băile 1 Mai Tourism System, Bihor County, Romania. Analele Universitatii din Oradea, Seria Geografie, 28(1), 131-137.

Herman, G. V., Tătar, C. F., \& Puşcaş, B. D. (2018b). Assessing the importance of the Jewish urban cultural heritage in Oradea, Bihor County, Romania. Forum Geografic, 17(2), 151-158.

Herman, G. V., Varodi, M. O., Grama, V., \& Morar, C. (2019b). Geographical Considerations Regarding the Tourist Destination Pădurea Craiului Mountains. Analele Universităţii din Oradea, Seria Geografie, 29(1), 102-108.

Herman, G., Ilies, D., Gaceu, O., Ilies, A., Mester, C., Ilies, M., ... \& Dumitru, M. (2019a). Some Considerations Concerning the Quality of Groundwater in the Natura 2000 Lunca Barcaului (Barcaului Meadow) Site, Romania. Journal of Environmental Protection and Ecology, 20(3), 1102-1109.

HG 1284/2007 privind declararea ariilor de protecție specială avifaunistica ca parte integrantă a rețelei ecologice europene Natura 2000 în România, Monitorul Oficial al României, Partea I, nr. 739/31.10.2007 [HG 1284/2007 on the declaration of special avifaunistic protection areas as an integral part of the European ecological network Natura 2000 in Romania, the Official Monitor of Romania, Part I, no. 739/31.10.2007/HG 1284/2007].

Hotararea 971 / 2011 pentru modificarea și completarea Hotărârii Guvernului nr. 1284/2007 privind declararea ariilor de protecție special avifaunistică ca parte integrantă a rețelei ecologice europene Natura 2000 în România, Monitorul Oficial al României, Partea I, nr. 715/11.10.2011 [Decision 971/2011 amending and supplementing the Government Decision no. 1284/2007 regarding the declaration of the special avifaunistic protection areas as an integral part of the European ecological network Natura 2000 in Romania, the Official Monitor of Romania, Part I, no. 715 / 11.10.2011].

Ianos, I., Peptenatu, D., \& Zamfir, D. (2009). Respect for environment and sustainable development. Carpathian journal of 
earth and environmental sciences, 4(1), 81-93.

Ilie, A. M., Herman, G. V., Ciobotaru, A. M., Grecu, A., Radu, R. A., Visan, M. C., \& Giurgia, M. (2017). The Role of Tourism in Structural Dynamics of the Economic Profile of Sighisoara City. Urbanism. Architecture. Constructions/Urbanism. Arhitectura. Constructii, 8(4), 377-386.

Ilieș D. C., Herman G. V., Dehoorne O., \& Măduţa F. (2013). The role and the importance of cyclotourism in the development of the Oradea Metropolitan Area (Romania), GeoJournal of Tourism and Geosites, 12(2): 101-110.

Ilieș, A., Wendt, J. A., Ilieș, D. C., Herman, G. V., Ilieș, M., \& Deac, A. L. (2016). The patrimony of wooden churches, built between 1531 and 2015, in the Land of Maramureș, Romania. Journal of Maps, 12(sup1), 597-602.

Ilieș, D. C., Baias, S., Buhaș, R., Ilieș, A., Herman, G. V., Gaceu, O., \& Măduța, F. (2017). Environmental education in protected areas. Case study from Bihor County, Romania. GeoJournal of Tourism and Geosites, 19(1), 126-132.

Ilieș, D. C., Buhas, R., Ilieș, M., Ilies, A., Gaceu, O., Pop, A. C., ... \& Baias, S. (2018). Sport activities and leisure in Nature 2000 protected area-Red Valley, Romania. Journal of Environmental Protection and Ecology, 19(1), 367-372.

Ilieș, D. C., Buhaș, R., Ilieş, A., Morar, C., \& Herman, G.V. (2015). Nymphaea Lotus Var. Thermalis (Pârâul Peţea Nature Reserve), Brand Near Extinction of the Băile Felix - Băile 1 Mai (Romania) Spa Tourism System. GeoJournal of Tourism and Geosites, 15(1): 107-117.

Ilieș, D. C., Herman, G., Ilieș, A., Baias, Ș., Dehoorne, O., Buhaș, S., \& Ungureanu, M. (2017). Tourism and Biodiversity in Natura 2000 Sites. Case Study: Natura 2000 Valea Roșie (Red Valley) Site, Bihor County, Romania. Études caribéennes, (37-38).

INS (2014). Suprafata fondului funciar dupa modul de folosinta, pe judete si localitati [Surface area of the agricultural real estate according to type of usage, and by counties and localities].

INS (2018). Innoptari in structuri de primire turistica pe tipuri de structuri, judete si localitati [Bed-nights in hospitality and tourist structures according to types of structures, counties, and localities].

INS (2018). Sosiri ale turistilor in structuri de primire turistica pe tipuri de structuri, pe judete si localitati [Tourist arrivals to hospitality structures according to types of structures, counties, and localities].

INS (2018). Structuri de primire turistica cu functiuni de cazare turistica pe tipuri de structuri, judete si localitati [Tourist hospitality structures featuring tourist accommodation facilities according to types of structures, counties, and localities].

INS (2019). Populatia dupa domiciliu la 1 iulie pe grupe de varsta si varste, sexe, judete si localitati [Population according to domicile on July 1st according to age and age groups, sex, counties, and localities].

Kacowicz, A. M. (1999). Regionalization, globalization, and nationalism: Convergent, divergent, or overlapping? Alternatives: Global, Local, Political, 24(4), 527-555.

Legea Nr. 5 din 6 martie 2000 privind aprobarea Planului de amenajare a teritoriului naţional - Secţiunea a III-a - zone protejate [Law no. 5 of 6th March 2000 on the approval of the National Territory Land Planning - Section III - protected areas], http://www.cdep.ro/pls/legis/legis_pck.htp_act_text?idt=22636

Olău, V. M. (2019). Post-Communist Demographic Changes in Pădurea Craiului Mountains. Revista Română de Geografie Politică, 21(2), 35-43.

Pires S.M., Fidélis T., \& Ramos T. B., (2014). Measuring and comparing local sustainable development through common indicators: Constraints and achievements in practice. Cities, Volume 39, Pages 1-9.

Rogerson C. M., (2015). Local Economic Development. In International Encyclopedia of the Social \& Behavioral Sciences (Second Edition), edited by James D. Wright, Elsevier, Oxford, 2015, Pages 279-283.

Rojanschi Vladimir, Bran Florina, Diaconu Simona, Grigore Florian, (2004), Evaluarea impactului ecologic şi auditul de mediu, Editura ASE, Bucuresti.

Sharpley, R., \& Telfer, D. J. (Eds.). (2015). Tourism and development: Concepts and issues (Vol. 63). Channel view publications.

Tătar, C. F., Herman, G. V., \& Gozner, M. (2018). Tourist Guides'contribution to Sustainability in Romania. GeoJournal of Tourism and Geosites, 21(1), 282-287.

Tătar, C. F., Herman, G. V., Dehoorne, O., \& Zarrilli, L. (2017). Ecotourism in the Danube Delta. Analele Universităţii din Oradea, Seria Geografie, 27(1): 122-132.

Wendt, J., Buhaș, R., \& Herman, G. V. (2019). Experience of the Baile-Felix Tourist System (Romania) For the Protection and Promotion of the Grey Seal as a Brend on the Hel Peninsular (Poland). Baltic Region/Baltijskij Region, 11(1): 109-116.

Xin, S., Tribe, J., \& Chambers, D. (2013). Conceptual research in tourism. Annals of Tourism Research, 41, 66-88.

www.cimec.ro

https://oradeaindirect.ro/cabana-vadu-crisului-va-fi-transformata-intr-un-centru-multifunctional/

http://alpinismbihor.ro

www.emenatura2000.ro

http://apmbh-old.anpm.ro/Mediu/Programe,\%20Proiecte,\%20Relatii\%20internationale-134

http://www.capdd-bihor.org/2018/03/28/lansarea-proiectului-imbunatatirea-starii-de-conservare-a-biodiversitatii-in-rospa0115-defileul-crisului-repede-valea-iadului/

https://www.transilvaniabusiness.ro/2019/11/13/defileul-crisului-repede-supravegheat-si-monitorizat-cu-22-de-camere-video/

Submitted:

Octomber 07, 2019
Revised:

November 05, 2019
Accepted and published online

November 21, 2019 